\title{
Collagenase production by human mononuclear cells in culture: inhibition by gold containing compounds and other antirheumatic agents*
}

\author{
AKIHIDE OHTA, ${ }^{1} 2$ JAMES S LOUIE, ${ }^{2}$ AND JOUNI UITTO ${ }^{1}$ \\ From the Department of Medicine, University of California, Los Angeles School of Medicine, Divisions of \\ ${ }^{I}$ Dermatology and ${ }^{2}$ Rheumatology, Harbor-UCLA Medical Center, Torrance, California
}

SUMMARY Human peripheral blood mononuclear cells in adherent cultures have been shown to synthesise and secrete collagenase. ${ }^{2}$ In the present study we have examined the modulation of collagenase production in these cultures by several antirheumatic agents. Incubation of monocytes in serum free medium with sodium aurothiomalate in concentrations varying from $7 \cdot 7 \times 10^{-7}$ to $7 \cdot 7 \times 10^{-3} \mathrm{~mol} / \mathrm{l}$ resulted in marked dose dependent inhibition of the collagenase production. This inhibition was apparently selective in that total protein synthesis or the viability of the cells were not affected. Similar inhibition of the collagenase production was also noted with auranofin, aurothioglucose, and chloroauric acid. The inhibition with auranofin was achieved with a concentration as low as $7 \cdot 4 \times 10^{-8} \mathrm{~mol} / \mathrm{l}$. To examine the mechanisms of the inhibition of the collagenase activity induced by sodium aurothiomalate the production of prostaglandin $\mathrm{E}_{20}$ was also measured in the same cell cultures. Sodium aurothiomalate in concentrations $>7 \cdot 7 \times 10^{-4} \mathrm{~mol} / \mathrm{l}$ significantly inhibited the prostaglandin $\mathrm{E}_{2}$ production; the prostaglandin $\mathrm{E}_{\overline{2}}$ production was not inhibited, however, in $7 \cdot 7 \times 10^{-5} \mathrm{~mol} / \mathrm{l}$ concentration, while the collagenase production was reduced by $51 \cdot 0 \%$. Also, exogenous prostaglandin $\mathrm{E}_{2}$ added to the cultures only slightly reversed the inhibition of the collagenase production by sodium aurothiomalate. Thus the inhibition of collagenase production by sodium aurothiomalate in human adherent mononuclear cell cultures appears to be independent of the inhibition of prostaglandin $\mathrm{E}_{2}$ production. The inhibition of collagenase produced by monocyte-macrophages, as shown here in vitro, may contribute to the clinical efficacy of the compounds tested in the treatment of rheumatoid arthritis.

Key words: monocytes, sodium aurothiomalate, auranofin.

Monocyte-macrophages, the hallmark of chronic inflammatory lesions, have been shown to produce a variety of proteases, which are thought to mediate tissue destruction in disease. ${ }^{34}$ We have recently shown that adherent mononuclear cells cultured from human peripheral blood actively synthesise and secrete collagenase which is similar to other mammalian collagenases in that it cleaves native type I collagen in a single locus at a distance three

Accepted for publication 5 June 1986.

Correspondence to Dr Jouni Uitto, Division of Dermatology. Harbor-UCLA Medical Center, 1000 West Carson Strect. Torrance, CA 90509 , USA.

*Presented at the 49th Annual Meeting of the American Rheumatism Association, Anaheim, CA. 4-8 Junc 1985.' quarters from the amino terminus. ${ }^{2}$ The enzyme, which is secreted in an active form, requires calcium for its activity. The activity is enhanced by sulphydryl reagents such as $N$-ethylmaleimide. ${ }^{2}$ The enzyme production was shown to be stimulated by concanavalin $\mathrm{A}$, and the total cumulative production in a 48 hour culture of the activated cells was shown to be of the same order of magnitude as the enzyme activity present in the same number of polymorphonuclear leucocytes. ${ }^{2}$ The enzyme production was shown to be exceptionally high in monocyte cultures established from three patients with haemochromatosis. ${ }^{2}$

The destructive lesion of rheumatoid arthritis is characterised by degradation of the collagenous matrix in articular joints, leading to resorption of 
bone and cartilage. ${ }^{5} 6$ The degradation of collagen is conceivably mediated by the multiple collagenases produced by the cells present in the rheumatoid joint, including synovial cells, polymorphonuclear leucocytes, and monocyte-macrophages. ${ }^{58} \mathrm{Be}-$ cause the tissue macrophages are derived from circulating monocytes, cultures of peripheral blood mononuclear cells provide a system for studying the effects of various pharmacological agents on collagenase production by these cells. In the present study we have examined the effects of various agents which are in clinical use for the treatment of rheumatoid arthritis. The results indicate that some but not all antirheumatic agents inhibit the production of collagenase by cultured mononuclear cells.

\section{Materials and methods}

MONONUCLEAR CELL CULTURES

Peripheral blood mononuclear cells from healthy volunteers or from three patients with haemochromatosis, whose monocytes had been previously shown to be active in synthesising and secreting collagenase, ${ }^{2}$ were isolated by density gradient centrifugation on Ficoll-Hypaque (Histopaque1077; Sigma Chemicals, St Louis, MO). ${ }^{9}$ The isolated mononuclear cells were pooled, washed in Hanks's balanced salt solution (HBSS), and suspended in serum free Dulbecco's modified Eagle's medium (DMEM; Gibco, Grand Island, NY) supplemented with $2 \mathrm{mM}$ L-glutamine, $100 \mathrm{U} / \mathrm{ml}$ penicillin, $100 \mu \mathrm{g} / \mathrm{ml}$ streptomycin, and $0 \cdot 2 \%$ lactalbumin hydrolysate (DMEM-LH; Sigma Chemicals, St Louis, MO). To establish the monocyte cultures $1-2 \times 10^{6}$ cells in $500 \mu$ l of DMEM-LH were plated in 24-well tissue culture plates (Corning, NY). The mononuclear cells were allowed to adhere for 120 min under $5 \% \mathrm{CO}_{2} / 95 \%$ air at $37^{\circ} \mathrm{C}$. The medium containing the non-adhered cells was then removed, the adherent cells were washed with $500 \mu \mathrm{l}$ of HBSS, and $500 \mu \mathrm{l}$ of fresh, serum free DMEM-LH was added to the cultures. To enhance the production of collagenase the culture medium was supplemented with $20 \mu \mathrm{g} / \mathrm{ml}$ concanavalin A (con A; Difco, Detroit, MI); the test compounds (see below) were added at the same time. The incubations were then continued for varying time periods up to 72 hours at $37^{\circ} \mathrm{C}$ under $5 \% \mathrm{CO}_{2} / 95 \%$ air.

\section{TEST COMPOUNDS}

The following agents were tested in the mononuclear cell cultures for their effects on collagenase production: sodium aurothiomalate (Merck, Sharp \& Dohme, West Point, PA); chloroauric acid trihydrate (Sigma, St Louis, MO); aurothioglucose (Sigma, St Louis, MO); auranofin ( $S$-triethyl- phosphine gold 2,3,4,6-tetra- $O$-acetyl-l-thio- $\beta$-Dglycopyranoside; Smith, Kline \& French Laboratories, Philadelphia, PA); indomethacin (Sigma, St Louis, MO); D-penicillamine ( $\beta, \beta$-dimethylcysteine; Merck, Sharp \& Dohme, West Point, PA); methylprednisolone sodium succinate (Abbott Laboratories, North Chicago, IL); prostaglandin $\mathrm{E}_{2}$ (Sigma, St Louis, MO). The test compounds were dissolved in DMEM-LH and then added to the incubation media in final concentrations indicated in the 'Results'. Sodium aurothiomalate, auranofin, indomethacin, D-penicillamine, and prostaglandin $E_{2}$ were initially dissolved in absolute ethyl alcohol and further diluted with DMEM-LH; the final concentrations of ethyl alcohol in the incubation media varied from $0.0002 \%$ to $1.92 \%(\mathrm{v} / \mathrm{v})$, and the parallel controls received the corresponding concentrations of ethanol. All test compounds in the concentrations used were soluble, with the exception of sodium aurothiomalate in $7.7 \times 10^{-3} \mathrm{~mol} / \mathrm{l}$ concentration which produced a visible precipitate.

For comparison, cultures consisting of polymorphonuclear leucocytes (PMNs) were also established. For this purpose PMNs were isolated from peripheral blood by a discontinuous Ficoll-Hypaque density gradient (combination of Histopaque-1077 and 1119; Sigma, St Louis, MO). ${ }^{10}$ The isolated PMNs were cultured in 24-well microtitre plates, $1 \times 10^{6}$ cells/well, as described above.

\section{COLLAGENASE ASSAY}

At different time points of cell incubation aliquots of the serum free media were assayed for collagenase activity by a sensitive, specific, and convenient method. ${ }^{11}$ In these assays $\left[{ }^{3} \mathrm{H}\right]$ proline labelled, native, triple helical type I collagen with a specific activity of $2.6 \times 10^{4} \mathrm{cpm} / \mu \mathrm{g}$ was used as substrate. Details of this assay procedure have been reported previously. "Briefly, in a standard assay the substrate $\left(3 \times 10^{4} \mathrm{cpm}\right.$ in $20 \mu \mathrm{l}$ of $0.01 \mathrm{M}$ acetic acid) was mixed with $10 \mu \mathrm{l}$ of $0.5 \mathrm{M}$ TRIS-HCl (trometamol), $\mathrm{pH} 7 \cdot 8$, containing $2 \cdot 0 \mathrm{M} \mathrm{NaCl}, 0.1 \mathrm{M} \mathrm{CaCl}_{2}$, and $0.1 \mathrm{M} \mathrm{N}$-ethylmaleimide (NEM), and with $10 \mu \mathrm{l}$ of a solution containing bovine serum albumin $0.2 \mathrm{mg} / \mathrm{ml}$. Aliquots $(60 \mu \mathrm{l})$ of the tissue culture supernatant to be assayed for collagenase activity were then added, and the incubations were continued for $120 \mathrm{~min}$ at $37^{\circ} \mathrm{C}$. The collagenase digestion was terminated by the addition of $50 \mu \mathrm{l}$ of $0.2 \mathrm{M}$ disodium ethylenediamine tetra-acetate ( $\mathrm{Na}_{2}$ EDTA). Unlabelled soluble type I collagen, trypsin, and $\alpha$-chymotrypsin in final concentrations of $0 \cdot 2,0 \cdot 16$, and $0 \cdot 16 \mathrm{mg} / \mathrm{ml}$, respectively, and dissolved in $0.2 \mathrm{M} \mathrm{NaCl}$ and $50 \mathrm{mM}$ TRIS- $\mathrm{HCl}$, $\mathrm{pH} 7 \cdot 5$, were then added to give a final volume of 
$400 \mu \mathrm{l}$; the incubations were continued for another 20 minutes at $37^{\circ} \mathrm{C}$. An equal volume of $20 \%(w / v)$ ice cold trichloroacetic acid (TCA) was then added, and the undigested, $\left[{ }^{3} \mathrm{H}\right]$ proline labelled substrate was precipitated by centrifugation. The radioactivity in the supernatant, representing collagen degradation, was counted with a liquid scintillation counter (Beckman LS-7500). Collagenase activity was expressed in units $(\mathrm{U})$, where $1 \mathrm{U}$ equals $1 \mu \mathrm{g}$ collagen degraded per minute.

For assay of intracellular collagenase activity the medium was removed and the adherent monocytes were rinsed with phosphate buffered saline. DMEM-LH $(500 \mu \mathrm{l})$ was added to each well, the cells were then detached by scraping with a rubber policeman, and homogenised with a Teflon-glass tissue homogeniser at $4^{\circ} \mathrm{C}$. The homogenates were centrifuged at $18000 \mathrm{~g}$ for $20 \mathrm{~min}$, and the supernatants were assayed for collagenase activity as above.

OTHER ASSAYS

Total protein synthesis by the cultured mononuclear cells was assayed by incubation of the cells with $30 \mu \mathrm{Ci}$ of $\left[\mathrm{L}-4,5-{ }^{3} \mathrm{H}\right]$ leucine (specific activity 151 $\mathrm{Ci} / \mathrm{mmol}$; Amersham) under conditions identical with those used for collagenase production. At the end of incubation protease inhibitors were added to the following final concentrations: $10 \mathrm{mmol} / \mathrm{l}$ $\mathrm{Na}_{2}$ EDTA, $10 \mathrm{mmol} / \mathrm{l} \mathrm{NEM}$, and $0.3 \mathrm{mmol} / \mathrm{l}$ phenylmethylsulphonyl fluoride. The adherent cells were detached by brief sonication, and the $\left[{ }^{3} \mathrm{H}\right]$ leucine labelled macromolecules in combined medium and cell fractions were precipitated by the addition of an equal volume of $20 \%$ TCA (w/v). The TCA precipitates were collected on Millipore prefilters (Millipore AP1502500; Millipore, Bedford, MA) on a vacuum manifold. The filters were air dried and counted in a Beckman LS-7500 liquid scintillation counter, as described previously. ${ }^{2}$

The viability of mononuclear cells was estimated by trypan blue dye exclusion test. ${ }^{12}$ The concentration of prostaglandin $E_{2}$ was measured by a radioimmunoassay. ${ }^{13}$

STATISTICAL ANALYSES

The results were evaluated for statistical significance by Student's $t$ test.

\section{Results}

INHIBITION OF COLLAGENASE PRODUCTION BY SODIUM AUROTHIOMALATE

The effects of antirheumatic agents on collagenase production were studied in adherent mononuclear cell cultures. We have shown that these cells synthesise and secrete collagenase in an active form, and the collagenase assays were performed in the presence of $10 \mathrm{mM} \mathrm{NEM}$, thus allowing the determination of total enzyme activity. ${ }^{2}$ In the first set of experiments sodium aurothiomalate was tested for its effect on collagenase production in adherent mononuclear cell cultures. Addition of sodium aurothiomalate in concentrations varying from $0.77 \mu \mathrm{mol} / \mathrm{l}$ to $7.7 \mathrm{mmol} / \mathrm{l}$ caused a significant reduction in collagenase production (Table 1 and Fig. 1a). This inhibition was not due to the salt form of the preparation, since sodium thiomalate in corresponding concentrations had no effect on the collagenase activity (Table 1).

To examine the possibility that sodium aurothiomalate might reduce the collagenase activity detectable in the cell culture media by directly inhibiting the collagenase assay, further in vitro experiments were performed. In these studies culture medium from the control cells was assayed for collagenase activity in the presence of sodium aurothiomalate in the same final concentrations as those present in the assays shown in Fig. 1. The addition of the gold compounds directly into the assay mixture had little, if any, effect on the collagenase activity (Fig. 1a).

In further experiments the activity of collagenas $\overrightarrow{0}$ associated with the cell layer either in contro cultures or in cultures incubated with $7.7 \mathrm{~m}$ sodium aurothiomalate was assayed. As indicated previously, ${ }^{2}$ very little intracellular enzyme activity was detectable in control monocyte cultures. In fact after 72 hours incubation the amount of enzyme $\mathbb{D}$ activity detectable in the cell layer of control cells was less than $1 \%$ of that found in the medium. Similarly, essentially no activity was present in sodium aurothiomalate treated cells. This observation excludes the possibility that sodium aurothiomalate interferes with the secretion of collagenase and suggests that the inhibition takes place on $\bar{\sigma}$ the level of enzyme production. Additional experiments indicated that mixing of a $30 \mu \mathrm{l}$ aliquot of $\delta$ control medium containing $29.6 \times 10^{-2} \mathrm{U}$ of collagenase activity and $30 \mu \mathrm{l}$ of cell extract with no $ᄋ$ detectable enzyme activity allowed the detection of $32 \cdot 1 \times 10^{-2} \mathrm{U}$ of enzyme activity. The latter result excludes the possibility that the cell extract contains an inhibitor for collagenase activity. Thus the reduc- $\sigma$ tion in collagenase activity present in the media $N$ of cultures treated with sodium aurothiomalate ap- N pears to result from reduced synthesis of the enzyme 0 protein, rather than reflecting inhibition of the secretory process. The demonstration that sodium $\stackrel{0}{\Phi}$ aurothiomalate minimally inhibited the con A stimu- $\stackrel{0}{?}$ lated release of PMN collagenase into the extra- 0 cellular milieu also supported the latter suggestion. Specifically, sodium aurothiomalate in $77 \mu \mathrm{mol} / 1 \mathbb{\Omega}$ 
Table 1 Effects of sodium aurothiomalate, sodium thiomalate, aurothioglucose, and chloroauric acid on the production of collagenase in human monocyte cultures*

\begin{tabular}{|c|c|c|c|c|}
\hline \multirow[t]{2}{*}{ Test compounds } & \multirow{2}{*}{$\begin{array}{l}\text { Concentration } \\
\text { (molll) }\end{array}$} & \multicolumn{2}{|c|}{ Collagenase production } & \multirow[t]{2}{*}{ p Value } \\
\hline & & $U \times 10^{-3} / 10^{6}$ cells $^{+}$ & $\%$ of control ${ }^{*}$ & \\
\hline Control & - & $20 \cdot 8 \pm 0 \cdot 6$ & $100 \cdot 0$ & 一 \\
\hline Ethanol alone $(0 \cdot 1 \%)$ & - & $22 \cdot 0 \pm 0 \cdot 2$ & $105 \cdot 8$ & NS \\
\hline Sodium aurothiomalate & $7.7 \times 10^{-7}$ & $7 \cdot 9 \pm 0 \cdot 4$ & $35 \cdot 9$ & $<0.001$ \\
\hline Sodium aurothiomalate & $7 \cdot 7 \times 10^{-6}$ & $3 \cdot 4 \pm 0 \cdot 2$ & $15 \cdot 5$ & $<0.001$ \\
\hline Sodium aurothiomalate & $7 \cdot 7 \times 10^{-5}$ & $2 \cdot 9 \pm 0 \cdot 2$ & $3 \cdot 2$ & $<0.001$ \\
\hline Sodium thiomalate & $7.7 \times 10^{-7}$ & $21 \cdot 7 \pm 0 \cdot 5$ & $104 \cdot 3$ & NS \\
\hline Sodium thiomalate & $7.7 \times 10^{-6}$ & $22 \cdot 7 \pm 0 \cdot 8$ & $109 \cdot 1$ & NS \\
\hline Sodium thiomalate & $7.7 \times 10^{-5}$ & $21 \cdot 8 \pm 0 \cdot 4$ & $104 \cdot 8$ & NS \\
\hline Aurothioglucose & $1.0 \times 10^{-6}$ & $11 \cdot 3 \pm 0 \cdot 4$ & $54 \cdot 3$ & $<0.001$ \\
\hline Aurothioglucose & $1.0 \times 10^{-5}$ & $7 \cdot 2 \pm 0 \cdot 3$ & $34 \cdot 6$ & $<0.001$ \\
\hline Aurothioglucose & $1.0 \times 10^{-4}$ & $2 \cdot 7 \pm 0 \cdot 3$ & $13 \cdot 0$ & $<0.001$ \\
\hline Chloroauric acid & $1.0 \times 10^{-6}$ & $9 \cdot 3 \pm 0 \cdot 2$ & $44 \cdot 7$ & $<0.001$ \\
\hline Chloroauric acid & $1.0 \times 10^{-5}$ & $2 \cdot 2 \pm 0 \cdot 2$ & $10 \cdot 6$ & $<0.001$ \\
\hline Chloroauric acid & $1.0 \times 10^{-4}$ & 0 & - & \\
\hline
\end{tabular}

*Adherent mononuclear cell cultures were established from peripheral blood, and the cells were incubated in serum free medium for 72 hours with or without the test compounds; collagenase activity in the culture media was then assayed as indicated in 'Materials and methods'.

${ }^{+}$The values are mean \pm SEM of four parallel cultures.

${ }^{\dagger}$ Calculated as a percentage from the corresponding control either with or without $0 \cdot 1 \%(\mathrm{v} / \mathrm{v})$ ethanol used as solvent for sodium aurothiomalate.

'Calculated by Student's $t$ test; NS=statistically not significant.

(a)

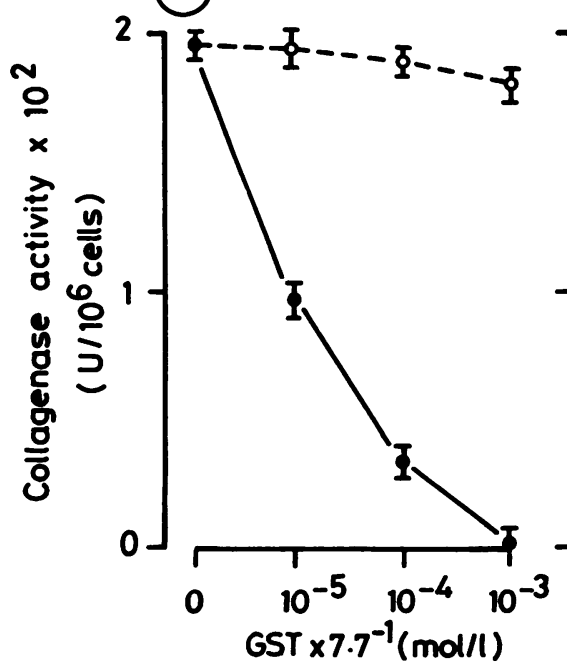

(b)

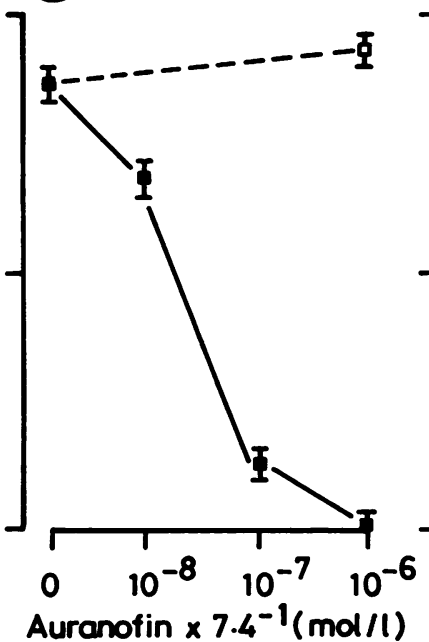

(c)

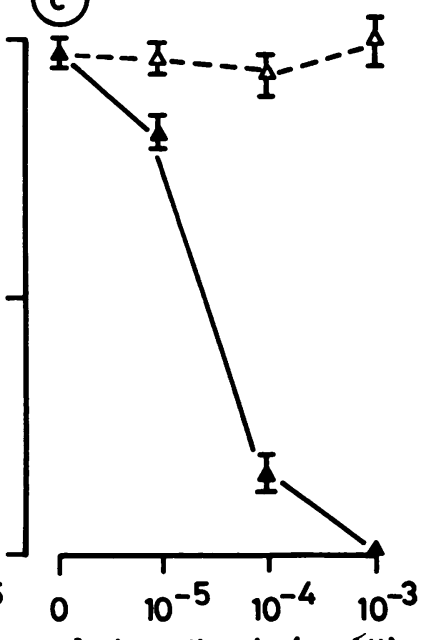

Fig. 1 Inhibition of monocyte collagenase production by sodium aurothiomalate (gold sodium thiomalate, GST), auranofin, and indomethacin. Adherent mononuclear cells isolated from human peripheral blood were incubated in serum free DMEM for 48 hours with the test compounds in concentrations indicated. Aliquots of the media were assayed for collagenase activity (-), as indicated in the text. Culture media from the control cells were also assayed for collagenase activity in the presence of each of the test compounds in the same final concentrations as were present in the assays described above (- - -). Collagenase activity was expressed in units $(U)$, where $1 U=1 \mu \mathrm{g}$ collagen degraded per minute. The values represent mean $\pm S E M$ from two parallel cultures each assayed in duplicate. 
concentration inhibited such release of the enzyme only by $16 \cdot 1 \%$.

Further experiments indicated that the viability of cells was not affected by the incubation with sodium aurothiomalate. In control cultures $92.8 \%$ of the cells excluded trypan blue, indicating viability; the corresponding viability values in cultures incubated with $77 \mu \mathrm{M}, 0.77 \mathrm{mM}$, or $7.7 \mathrm{mM}$ sodium aurothiomalate were $94.8 \%, 92.7 \%$, and $95.9 \%$, respectively.

To assess the selectivity of the sodium aurothiomalate induced inhibition of the monocyte collagenase production, total protein synthesis was determined. For this purpose mononuclear cells were preincubated with $77 \mu \mathrm{M}$ sodium aurothiomalate for $30 \mathrm{~min}, 23$ hours, or 47 hours and pulse

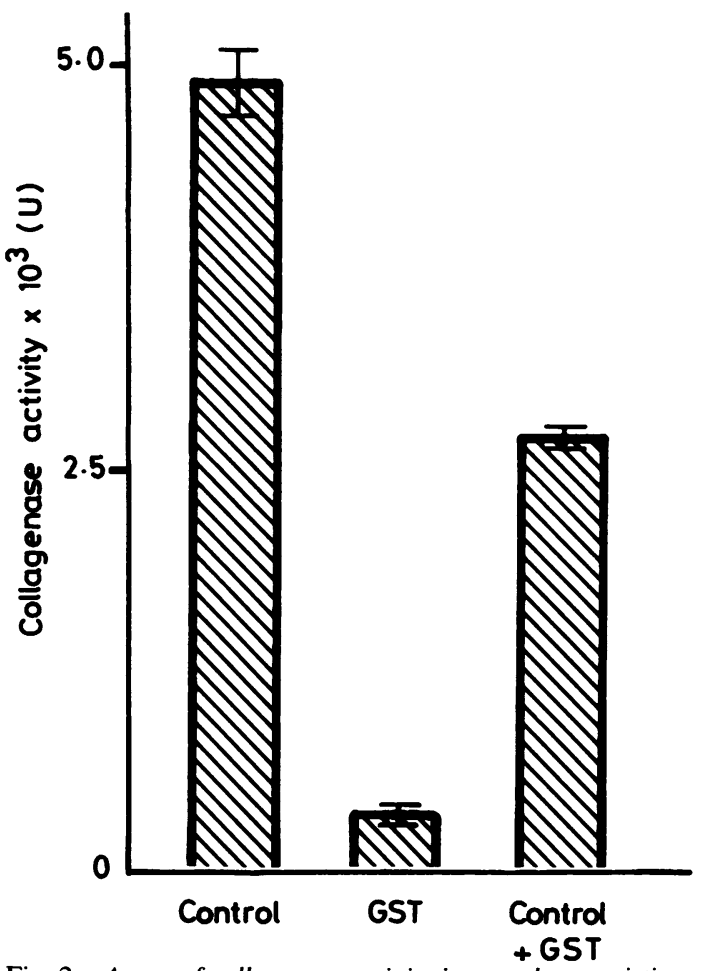

Fig. 2 Assay of collagenase activity in samples consisting of mixed aliquots of control media and media from cell cultures incubated with sodium aurothiomalate. Adherent mononuclear cell cultures were incubated without (control) or with $77 \mu M$ sodium aurothiomalate (GST), as indicated in Fig. 1a. Aliquots $(60 \mu l)$ of the control and sodium aurothiomalate media showed collagenase activity, as indicated in the figure. Mixing of $30 \mu l$ of both control and cell culture media treated with sodium aurothiomalate resulted in a value average between the original samples. The values are mean $\pm S E M$ from three parallel determinations. labelled with [ $\left[{ }^{3} \mathrm{H}\right]$ leucine for $60 \mathrm{~min}$; the incorporation of radioactivity into TCA precipitable macromolecules was then determined. The results indicated that at all three time points examined the total protein synthesis in sodium aurothiomalate treated cultures was the same as that in the control cultures containing the corresponding concentration of ethanol $\left(3 \times 10^{-4 \%}(\mathrm{v} / \mathrm{v})\right)$ used as solvent (results not shown). Thus the reduction in collagenase produc- कै tion by sodium aurothiomalate is not a reflection of $\overrightarrow{0}$ generalised inhibition of total protein synthesis.

Finally, mixing experiments were performed to $\vec{\omega}$ exclude the possibility that sodium aurothiomalate rather than inhibiting collagenase production, in- 흐 duced the synthesis of an inhibitor of the enzyme of activity. Mixing of equal volumes of control medium $\vec{N}$ with medium from cell cultures incubated with $0.77 \mathrm{mM}$ sodium aurothiomalate (which contained 8 collagenase activity of about $4.9 \%$ of that detectable $\circ$ in control medium) resulted in a value average between the original samples (Fig. 2). Thus no 0 evidence for induction of a collagenase inhibitor, in excess of the active collagenase, in the presence of sodium aurothiomalate was observed.

INHIBITION OF COLLAGENASE PRODUCTIO BYOTHER GOLD CONTAINING COMPOUNDS Several additional compounds were tested in mono응 nuclear cell cultures. Addition of auranofin in concentrations varying from $7 \cdot 4 \times 10^{-8}$ to $7 \cdot 4 \times 10^{-4} \frac{\partial}{\partial}$ $\mathrm{mol} / \mathrm{l}$ significantly inhibited the collagenase produc- ڤँ tion (Fig. 1b). Again, addition of auranofin directly $\mathbb{\mathbb { Q }}$ into the assay system in concentration present during the enzyme measurements from media containing $7 \cdot 4 \times 10^{-6} \mathrm{~mol} / \mathrm{l}$ auranofin had little, if any, effect on the activity of control enzyme (Fig. 1b). The viability of cells incubated with auranofin in concentrations up to $7 \cdot 4 \times 10^{-6} \mathrm{~mol} / \mathrm{l}$ was unaffected. The viability of cells incubated with $7.4 \times 10^{-5}$ or $7 \cdot 4 \times 10^{-4} \mathrm{~mol} / \mathrm{l}$ auranofin, however, was slightly reduced when tested by trypan blue exclusion $\mathbf{( 8 4 . 2}$. and $71 \cdot 1 \%$, respectively, $v 92.8 \%$ of cells viable in control cultures). Nevertheless, the incorporation of 을 radioactive leucine, as an index of total protein $\rightarrow$ synthesis, was not reduced in the presence of $7 \cdot 4 \times 10^{-7} \mathrm{~mol} / \mathrm{l}$ of auranofin, as compared with controls (not shown).

Two additional gold containing compounds, auro- $\tilde{O}$ thioglucose and chloroauric acid, also proved $\underset{\omega}{\omega}$ inhibitory for collagenase production (Table 1).

D-PENICILLAMINE AND

METHYLPREDNISOLONE DO NOT

AFFECT COLLAGENASE PRODUCTION

In further experiments two additional agents which 


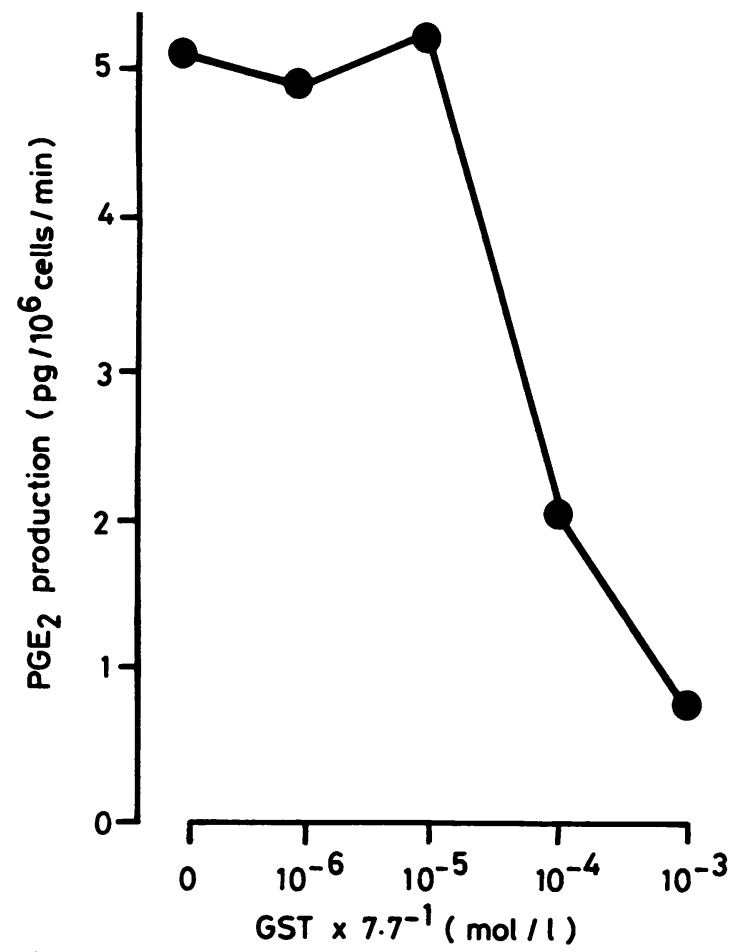

Fig. 3 Effect of sodium aurothiomalate (GST) on the production of prostaglandin $E_{2}\left(P G E_{2}\right)$ in adherent mononuclear cell cultures. $P G E_{2}$ production was determined by a radioimmunoassay in the same cultures as shown in Fig. la. The individual values are means of two parallel determinations.

are in clinical use were tested for their effects on collagenase production. D-Penicillamine in 25 and $100 \mu \mathrm{g} / \mathrm{ml}$ had no effect on collagenase production in mononuclear cell cultures. Similarly, incubation of the cells for 48 hours with methylprednisolone in concentrations varying from $10^{-9}$ to $10^{-7} \mathrm{~mol} / \mathrm{l}$ had no effect on the enzyme activity (results not shown).

INHIBITION OF PROSTAGLANDIN $E_{2}$

PRODUCTION BY SODIUM AUROTHIOMALATE Previous studies have suggested that the modulation of collagenase production by a variety of cells might involve the prostaglandin pathway. ${ }^{14-16}$ In order to examine the relation between the reduced collagenase production and the prostaglandin pathway the production of prostaglandin $\mathrm{E}_{2}\left(\mathrm{PGE}_{2}\right)$ in the mononuclear cell cultures incubated with sodium aurothiomalate was also assayed. The results indicated that sodium aurothiomalate in $7 \cdot 7 \times 10^{-4} \mathrm{~mol} / \mathrm{l}$ concentration reduced the production of $\mathrm{PGE}_{2}$ by $60.4 \%$ (Fig. 3); the collagenase production in the same cultures was reduced by $66.4 \%$ (Fig. 1a). In cultures incubated with $7 \cdot 7 \times 10^{-5} \mathrm{~mol} / \mathrm{l}$ sodium aurothiomalate, however, the $\mathrm{PGE}_{2}$ production was unaffected (Fig. 3), yet the collagenase production was reduced by $51 \cdot 0 \%$ (Fig. 1a).

In further experiments an attempt was made to reverse the sodium aurothiomalate induced inhibition of the collagenase production by addition of exogenous $\mathrm{PGE}_{2}$. The initial results indicated that the addition of $\mathrm{PGE}_{2}$ alone in $10^{-9}$ or $10^{-7} \mathrm{~mol} / \mathrm{l}$ concentration had little, if any, effect on the collagenase activity in mononuclear cell cultures (Fig. 4a). The results further indicated that the inhibition noted in the presence of $7 \cdot 7 \times 10^{-5} \mathrm{~mol} / \mathrm{l}$ sodium aurothiomalate could be only partially reversed by the addition of exogenous $\mathrm{PGE}_{2}$ (Fig. 4b).

In parallel experiments the production of $\mathrm{PGE}_{2}$ was inhibited by incubation of cells with indomethacin. As expected, indomethacin in $10^{-5}$ and $10^{-4} \mathrm{~mol} / \mathrm{l}$ concentrations completely inhibited the production of $\mathrm{PGE}_{2}$ (not shown). In the same cultures the production of collagenase was reduced by $18.1 \%$ and $53 \cdot 2 \%$, respectively (Fig. 1c).

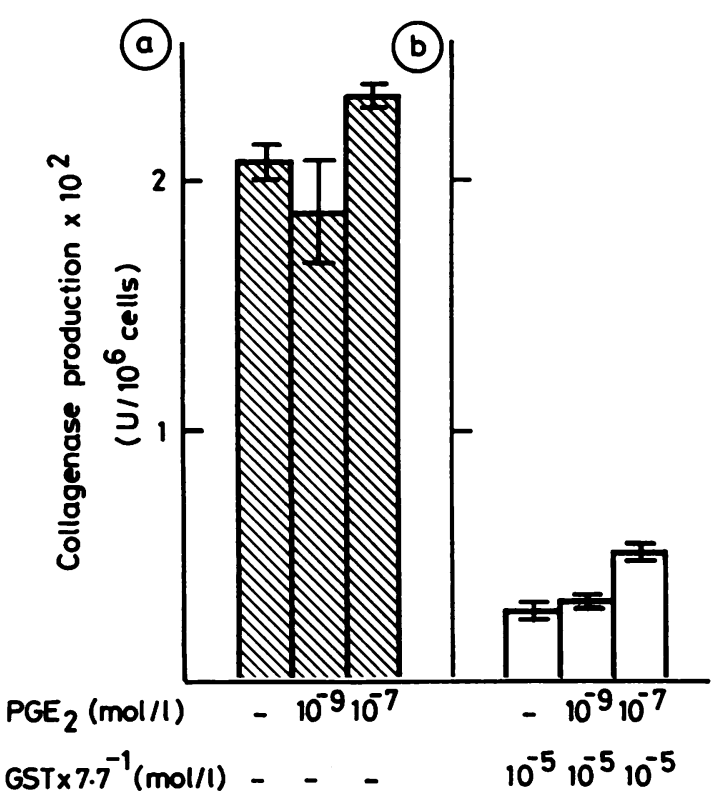

Fig. 4 Effects of exogenous prostaglandin $E_{2}\left(P G E_{2}\right)$ on sodium aurothiomalate induced inhibition of collagenase production in adherent mononuclear cell cultures. The cells were incubated with prostaglandin $E_{2}$ and sodium aurothiomalate (GST) in the concentrations indicated. Aliquots of the media were tested for collagenase activity, as described in the text. The values are mean $\pm S E M$ from four parallel determinations. 


\section{Discussion}

In this study we have shown that several gold containing compounds readily inhibit the production of collagenase by adherent mononuclear cells in culture. These cells were activated by incubation with con A, and they actively synthesised and secreted collagenase. Two of the gold containing compounds, - namely, sodium aurothiomalate and auranofin, are in clinical use for treatment of rheumatoid arthritis. The inhibition of monocyte collagenase production by sodium aurothiomalate was achieved in vitro with concentrations which correspond to tissue levels clinically obtainable. ${ }^{17}$ Specifically, previous studies have detected a concentration as high as $3 \times 10^{-5} \mathrm{~mol} / \mathrm{l}$ in synovial tissue after sodium aurothiomalate administration. ${ }^{18}$ Also, serum concentrations of $2-5 \times 10^{-5} \mathrm{~mol} / \mathrm{l}$ can be attained and levels of $1-1.5 \times 10^{-5} \mathrm{~mol} / \mathrm{l}$ are maintained during sodium aurothiomalate therapy. ${ }^{18} 19$ These values are clearly within the inhibitory range noted in our study. It is conceivable, therefore, that the inhibition of collagenase production, as observed in monocyte cultures, may contribute to the clinical efficacy of these compounds in vivo. It should be noted that the gold containing compounds can have multiple, independent effects on other macrophage functions, including chemotactic responsiveness, ${ }^{20}$ phagocytic activity, ${ }^{21} 22$ and secretion of other macrophage enzymes. ${ }^{23}$ All these effects can contribute to the clinical response achieved by these compounds.

The mechanism of the inhibition of collagenase production in mononuclear cell cultures appears to involve inhibition of the enzyme protein synthesis. In support of this conclusion were several observations: Firstly, little, if any, intracellular enzyme could be detected in the cultures in which the collagenase production was inhibited, indicating that the inhibition was not due to a block in the secretion of the newly synthesised collagenase. Secondly, the compounds had no direct effect on the collagenase activity when added directly in vitro into the assay used for the enzyme determinations. Thirdly, the compounds had no effect on cell viability, as determined by the trypan blue exclusion test. Thus the inhibitory compounds appear to exert their effects on the level of collagenase gene expression. It is currently unknown, however, whether they affect the collagenase production by interfering with the rate of transcription of the collagenase gene or whether they alter the translational activity of the messenger ribonucleic acid (RNA) molecules corresponding to the collagenase protein. The mechanistic details of the inhibition will be addressed in further studies using collagenase specific cDNA probes which are currently being developed. ${ }^{24}$

It is of interest that two other pharmacological $\overrightarrow{\vec{B}}$ compounds clinically used for the treatment of $\stackrel{\rho}{\rightarrow}$ rheumatoid arthritis, D-penicillamine and methylprednisolone, were not effective inhibitors of col- $\frac{\bar{D}}{\bar{D}}$ lagenase at the concentration levels which are $\frac{\pi}{\overparen{ }}$ conceivably achievable in vivo. These observations $\cong$ indicate that the beneficial effects of D-penicillamine $\stackrel{\infty}{\infty}$ in rheumatoid arthritis are attributable to other $\vec{\circ}$ mechanisms which may involve modulation of the immunological and metabolic aspects of this $\vec{\omega}$ disease. ${ }^{25}$ Previously it has been shown that the secretion of collagenase by mouse peritoneal macrophages is decreased by dexamethasone, cortisol, and iे triamcinolone acetonide. ${ }^{26}$ In the present study, $\vec{N}$ however, methylprednisolone was not found to be an effective inhibitor of the production of collage- $\mathscr{\odot}$ nase by human mononuclear cells when tested in 음 concentrations up to $10^{-7} \mathrm{~mol} / \mathrm{l}$.

Previous studies have suggested that collagenase $\overrightarrow{0}$ production in a variety of cell systems may involve the prostaglandin pathway. ${ }^{27}$ For example, produc- $\frac{\mathscr{Q}}{3}$ tion of collagenase by synovial cells was decreased with inhibition of $\mathrm{PGE}_{2}$ by the addition of indos methacin. Furthermore, indomethacin-induceg $\vec{\circ}$ reduction of the level of collagenase could restored by $\mathrm{PGE}_{2} \cdot{ }^{27}$ Similarly, peritoneal mas rophages activated by endotoxin produced less collagenase in the presence of indomethacin $;{ }^{14}$ this inhibition could also be overcome by the addition of exogenous $\mathrm{PGE}_{2}$. These observations thus suggest $\mathbb{D}$ an association between the collagenase production and prostaglandin pathway but do not prove a dependent relationship. In the present study sodium aurothiomalate markedly inhibited the production of $\mathrm{PGE}_{2}$. Sodium aurothiomalate in a concentration of $7 \cdot 7 \times 10^{-5} \mathrm{~mol} / \mathrm{l}$, however, had no effect on $\mathrm{PGE}_{2}$ production, while the collagenase production in the same cells was markedly reduced. At the same time, addition of exogenous $\mathrm{PGE}_{2}$ failed to increase the $ᄋ$ collagenase production in mononuclear cell cultures $₹$ or had only a small reversing effect on the sodium $\frac{9}{2}$ aurothiomalate induced inhibition of the collage- $D$ nase production. It appears, therefore, that the inhibition of the collagenase production by sodium $\vec{N}$ aurothiomalate is independent of the modulation of $\%$ $\mathrm{PGE}_{2}$ in monocyte cultures. This observation does $\mathbb{\sim}$ not exclude the possibility that other mediators of the prostaglandin pathway, such as $\mathrm{PGE}_{2 \alpha}$, might participate in the collagenase modulation.

Rheumatoid arthritis is a complex connective $\frac{0}{D}$ tissue disorder in which several different immunolo- $\stackrel{\mathcal{D}}{?}$ gical and biochemical mechanisms contribute to the 0 disease process. ${ }^{28-30}$ In an affected rheumatoid joint, collagen metabolism is altered at least at two 
different levels. Firstly, the active proliferative phase of pannus formation is characterised by increased biosynthesis of collagen and activated fibroblast proliferation, resulting in excessive deposition of connective tissue. ${ }^{31}{ }^{32}$ At the same time there is degradation of collagen, resulting in destruction of the cartilage and ligaments, and resorption of the bones. ${ }^{56}$ The degradation of collagen is apparently mediated by a variety of collagenases which can originate from the synovial cells, fibroblasts, polymorphonuclear leucocytes, and monocytemacrophages. Thus the inhibition of collagenase production by gold containing compounds, including sodium aurothiomalate and auranofin, as shown here in monocyte cultures, may contribute to the clinical efficacy of these compounds in vivo.

Dr Robert D Zipser kindly assisted in prostaglandin $E_{2}$ assays. The authors thank Irma Loper for skillful technical assistance, and Charlene D Aranda for secretarial help. Supported in part by USPHS. NIH grants AM-28450, GM-28833, and AM-35297 and by grants from the Arthritis Foundation. Southern California Chapter, and the American Diabetes Association, Southern California Affiliate.

\section{References}

1 Ohta A. Louie J S. Uitto J. Inhibition of human monocyte collagen production by anti-rheumatic agents [Abstract]. Arthritis Rheum 1985; 28 (suppl 1): 544.

2 Louie J S, Weiss J, Ryhänen L, Nies K M, Rantala-Ryhänen S, Uitto $\mathrm{J}$. The production of collagen by adherent mononuclear cells cultured from human peripheral blood. Arthritis Rheum 1984: 27: 1397-404.

3 Nathan C F, Murray H W, Cohn Z A. The macrophage as an effector cell. $N$ Engl J Med 1980; 303: 622-6.

4 Davies P. Bonney R J, Humes J L, Kuehl F X. Secretory functions of macrophages participating in inflammatory responses. In: Dingle J T, Gordon S, eds. Cellular interactions. Amsterdam: Elsevier/North Holland, 1984: 33-42.

5 Harris E D Jr, Krane S M. Collagenases. N Engl J Med 1974; 291: 557-63, 605-9, 652-61.

6 Harris E D Jr. Faulkner C S. Brown F E. Collagenolytic systems in rheumatoid arthritis. Clin Orthop 1975; 110: 303-16.

7 Harper E. Collagenases. Ann Rev Biochem 1980; 69: 1063-78.

8 Harris E D Jr, Welgus H G. Krane S M. Regulation of the mammalian collagenases. Collagen Relat Res 1984; 4: 493-512.

9 Boyum A. Separation of leukocytes from blood and bone marrow. Scand J Clin Lab lnvest 1968; 21(suppl 97): 77-89.

10 English D. Anderson B R. Single-step separation of red blood cells, granulocytes and mononuclear leukocytes on discontinuous density gradients of Ficoll-Hypaque. J Immunol Methods 1974; 5: 269-72.

11 Ryhänen L. Rantala-Ryhänen S. Tan E M. Uitto J. Assay of collagenase activity by a rapid, sensitive and specific method. Collagen Relat Res 1982; 2: 117-30.

12 Phillips H J. Dye exclusion test for cell viability. In: Kruse Jr P F, Patterson Jr M K, eds. Tissue culture, methods and applications. New York: Academic Press, 1973: 406-8.
13 Zipser R D, Myers S I, Needleman P. Stimulation of renal prostaglandin synthesis by the pressor activity of vasopressin. Endocrinology 1981; 108: 495-9.

14 Wahl L M, Olsen C E, Sandberg A L, Mergenhagen S E. Prostaglandin regulation of macrophage collagenase production. Proc Natl Acad Sci USA 1977; 74: 4955-8.

15 Dayer J M, Breard J, Chess L, Krane S M. Participation of monocyte-macrophages and lymphocytes in the production of a factor that stimulates collagenase and prostaglandin release by rheumatoid synovial cells. J Clin Invest 1979; 64: 1368-92.

16 Dayer J M. Krane S M, Roelke M S. Effect of prostaglandin $E_{2}$, indomethacin, trifluoperazine and drugs affecting the cytoskeleton on collagenase production by cultured adherent rheumatoid synovial cells. Biochem Pharmacol 1984; 33: 2893-9.

17 Lewis A J, Walz D T. Immunopharmacology of gold. In: Ellis G P, West G B, eds. Progress in medicinal chemistry. Amsterdam: Elsevier, 1982: 1-58.

18 Gerber R C, Paulus H E, Bluestone R. Lederer M. Kinetics of aurothiomalate in serum and synovial fluid. Arthritis Rheum 1972; 15: 625-9.

19 Lorber A, Cohen R L, Chang C C, Anderson H E. Gold determination in biological fluids by atomic absorption spectrophotometry: application to chrysotherapy in rheumatoid arthritis patients. Arthritis Rheum 1968; 11: 170-7.

20 Ho P P K, Young A L. Southard G L. Methyl ester of $N$ formylmethionyl-leucyl-phenylalanine. Chemotactic responses of human blood monocytes and inhibition of gold compounds. Arthritis Rheum 1978; 21: 133-6.

21 Lipsky P E, Ugai K, Ziff M. Alterations in human monocyte structure and function induced by incubation with gold sodium thiomalate. J Rheumatol 1979; 6 (suppl 5): 130-6.

22 Ugai K, Ziff M, Lipsky P K. Gold-induced changes in the morphology and functional capabilities of human monocytes. Arthritis Rheum 1979; 22: 1352-60.

23 Moroz L A. Effects of gold sodium thiomalate on fibrinolysis. J Rheumatol 1979; 6 (suppl 5): 149-53.

24 Gross R M, Sheldon L A, Fletcher D F, Brinckerhoff C E. Isolation of a collagenase cDNA clone and measurement of changing collagenase mRNA levels during induction in rabbit synovial fibroblasts. Proc Natl Acad Sci USA 1984; 81: 1981-5.

25 Jaffe J A. D-Penicillamine. Bull Rheum Dis 1978; 28: 948-52.

26 Werb Z. Biochemical actions of glucocorticoids on macrophages in culture. Specific inhibition of elastase, collagenase, and plasminogen activator secretion and effects on other metabolic functions. J Exp Med 1978; 147: 1695-712.

27 Dayer J M, Golding S R, Robinson D R, Krane S M. Cell-cell interactions and collagenase production. In: Woolley $D E$, Evanson J M, eds. Collagenase in normal and pathological connective tissues. Chichester: Wiley, 1980: 83-104.

28 Krane SM. Joint erosion in rheumatoid arthritis. Arthritis Rheum 1974: 17: 306-12.

29 Silver R M, Zvaifler N J. Immunologic considerations. In: Utsinger P D, Zvaifler N J, Ehrlich G E, eds. Rheumatoid arthritis. Philadelphia: Lippincott, 1985: 71-89.

$30 \mathrm{Korn} \mathrm{J} \mathrm{H}$. Cellular and biochemical interactions in the rheumatoid joint. In: Utsinger P D, Zvaifler N J, Ehrlich G E. Rheumatoid arthritis. Philadelphia: Lippincott, 1985: 90-105.

31 Uitto J, Lindy S, Turto $\mathrm{H}$, Vainio $\mathrm{K}$. Collagen biosynthesis in rheumatoid synovial tissue. J Lab Clin Med 1972; 78: 960-71.

32 Harris E D Jr. Recent insights into the pathogenesis of the proliferative lesion in rheumatoid arthritis. Arthritis Rheum 1976 19: 68-72. 